
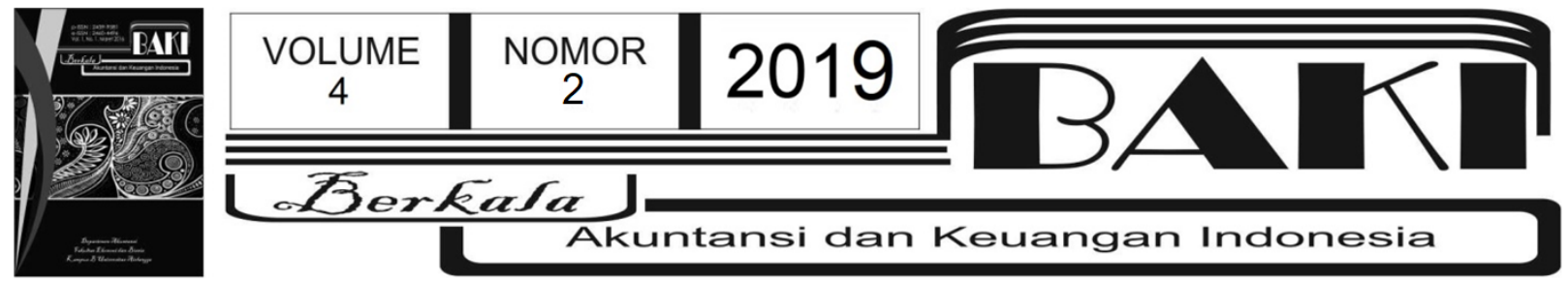

\title{
Implementasi SAK EMKM Dan Pengaruhnya Terhadap Penerimaan Kredit UMKM
}

\author{
Siti Mubiroh ${ }^{1,2}$, \\ Zulfatun Ruscitasari ${ }^{1,3}$ \\ 1,2 Universitas Nahdlatul Ulama Yogyakarta \\ 2mubiroh@unu-jogja.ac.id \\ zzulfatunr@unu-jogia.ac.id
}

INFO ARTIKEL

Histori Artikel:

Tanggal Masuk 11 September 2019

Tanggal Diterima 20 September 2019

Tersedia Online 30 September 2019

Kata Kunci:

UMKM, SAK EMKM, Kredit UMKM,

\begin{abstract}
ABSTRAK
UMKM merupakan ujung tombak perekonomian di suatu negara. Keberadaan UMKM dapat menyelematkan negara dari krisis ekonomi, terlihat dari krisis yang terjadi pada Tahun 1998 dan 2008. Jumlah pengangguran dapat teratasi karena penyerapan tenaga kerja UMKM mencapai $96 \%$ dari total tenaga kerja di Indonesia. Namun, keberlangsungan operasional UMKM sering terkendala pada akses pendanaan. Kendala tersebut disebabkan oleh kurangnya kualitas laporan keuangan UMKM. Hal tersebut mengakibatkan perbankan atau lembaga keuangan lain lebih berhati-hati dalam memberikan pinjaman kepada UMKM. Penelitian ini betujuan untuk mengetahui implementasi SAK EMKM dengan menggunakan variabel ukuran perusahaan, latar belakang pendidikan pemilik, dan pemberian informasi dan sosialisasi SAK EMKM. selain itu, tujuan penelitian ini untuk menguji pengaruh SAK EMKM terhadap kualitas laporan keuangan UMKM, dan pengaruh kualitas laporan keuangan terhadap penerimaan kredit UMKM. Penelitian ini menggunakan pendekatan kuantitatif dengan metode survei yaitu menyebarkan kuesioner kepada pelaku UMKM di Daerah Istimewa Yogyakarta. Teknik pengambilan sampel menggunakan random sampling. Data diolah menggunakan SPSS dengan alat analisis regresi berganda. Hasil penelitian ini menunjukkan bahwa variabel ukuran perusahaan dan latar belakang pendidikan pemilik UMKM tidak berpengaruh signifikan terhadap implementasi SAK EMKM. Sedangkan variabel pemberian sosialisasi dan informasi berpengaruh signifikan terhadap implementasi SAK EMKM. Kemudian, variabel implementasi SAK EMKM berpengaruh signifikan terhadap kualitas laporan keuangan, dan variabel kualitas laporan keuangan tidak berpengaruh signifikan terhadap penerimaan kredit UMKM.
\end{abstract}




\section{Pendahuluan}

UKM memainkan peran penting dalam proses pertumbuhan ekonomi di suatu negara (Jaffar et al., 2011; Chakraborty 2015) Baik negara-negara maju maupun negara berkembang (Clementina et al.,2014). UKM telah diakui sebagai kontributor terbesar bagi perekonomian negara yang menawarkan lapangan pekerjaan dan platform ide-ide inovatif (Kung'u 2011).

Jumlah UMKM di Indonesia kurang lebih 57.8 juta unit atau 99.9\% dari seluruh unit usaha. UMKM juga dapat dijadikan sebagai solusi dalam mengatasi masalah pengangguran di Indonesia. Hal tersebut terlihat dari banyaknya penyerapan tenaga kerja pada UMKM sebesar 114.4 juta atau 96,99 \% dari seluruh tenaga kerja di Indonesia (Departemen Koperasi 2013).

Namun, UMKM mengalami kendala dalam akses pendanaan baik dari perbankan maupun dari lembaga keuangan lainnya. Bank dan lembaga keuangan lainnya merupakan salah satu sumber pendanaan UMKM. Tetapi bank dan lembaga keuangan lainnya menghadapi kesulitan untuk menilai proposal pinjaman dari UMKM yang tidak memiliki catatan akuntansi dan keuangan yang tepat. Salah satu penyebabnya adalah struktur kepemilikan UMKM biasanya berupa individu atau anggota keluarga. Sehingga tidak adanya akuntabilitas publik, kurangnya aturan yang mendukung, tidak adanya audit atas laporan keuangan, dan kurangnya sumber daya (Chakraborty 2015).

Dewan Standar Akuntansi Keuangan (DSAK) telah menyusun dan mengesahkan Standar Akuntansi Keuangan Entitas Tanpa Akuntabilitas Publik (SAK ETAP) yang berlaku efektif pada Tanggal 1 Januari 2011. DSAK Berharap dengan disahkan SAK ETAP dapat meningkatkan kualitas laporan keuangan UMKM.

Penelitian sebelumnya menunjukkan hasil bahwa sebagian besar pelaku UMKM di Indonesia belum melakukan pencatatan sesuai dengan SAK ETAP karena terdapat kendala dalam implementasinya. Kendala utamanya adalah masih rendahnya pemahaman pelaku UMKM terkait SAK ETAP dikarenakan pemberian informasi dan sosialisasi yang belum efektif (Rudiantoro dan Siregar 2012). Menurut pengusaha UMKM pencatatan akuntansi hanya membuang waktu dan biaya. Bagi mereka yang terpenting adalah cara menghasilkan laba sebanyak mungkin tanpa dibebani dengan pencatatan akuntansi (Kurniawanysah 2016). Kualitas laporan keuangan dapat berdampak pada besarnya pemberian kredit oleh perbankan kepada UMKM (Rahmawat dan Puspasari 2017). Hasil penelitian tersebut menunjukkan bahwa implementasi SAK ETAP belum optimal.

DSAK kemudian menyusun standar akuntansi baru yaitu Standar Akuntansi Keuangan Entitas Mikro, Kecil, dan Menengah (SAK EMKM). Penerapan SAK EMKM tersebut berlaku efektif per Tanggal 1 Januari 2018. SAK EMKM ditujukan untuk entitas yang tidak atau belum 
mampu memenuhi persyaratan akuntansi yang diatur dalam SAK ETAP dan tidak memberikan kriteria golongan entitas mikro, kecil, dan menengah (DSAK 2016). Dengan demikian, SAK EMKM ditujukan untuk UMKM secara menyeluruh agar UMKM dapat menyusun laporan keuangan yang berkualitas.

Dari penjelasan di atas maka pertanyaan penelitian ini adalah, (1) faktor apa saja yang mempengaruhi implementasi SAK EMKM, (2) apakah implementasi SAK EMKM berpengaruh signifikan terhadap kualitas laporan keuangan UMKM, dan (3) apakah kualitas laporan keuangan berpengaruh signifikan terhadap penerimaan kredit UMKM. Penelitian ini bertujuan untuk mengetahui secara empiris implementasi SAK EMKM melalui faktor-faktor yang mempengaruhi implementasi SAK EMKM serta pengaruhnya terhadap penerimaan kredit UMKM.

\section{Tinjauan Pustaka}

\subsection{UMKM}

UKM adalah entitas yang tidak memiliki persyaratan untuk menyusun laporan keuangan. Aset UKM tidak dimiliki oleh sekelompok investor luar (Bank, perusahaan asuransi, pialang sekuritas, dII) tetapi dimiliki oleh pemilik yang biasanya juga merupakan pengelola (Maseko dan Onias 2011). UKM di Malaysia dikategorisasi berdasarkan jumlah karyawan dan total pendapatan atau penjualan yang dihasilkan dalam satu tahun (Jaffar et al., 2011).

Sedangkan kreteria UMKM di Indonesia yaitu usaha yang memiliki aset bersih RP.50.000.000 (mikro), lebih dari Rp.50.000.000 sampai RP.500.000.000 (kecil), lebih dari Rp.500.000.000 sampai Rp. 10.000.000.000 (menengah) tidak termasuk tanah dan bangunan. Serta memiliki omset Rp. 300.000 .000 pertahun (mikro), lebih dari Rp. 300.000 .000 sampai Rp. 2.500.000.000 pertahun (kecil), dan omset lebih dari Rp. 2.500.000.000 sampai Rp.10.000.000.000 pertahun (menengah) (Undang-undang Republik Indonesia No. 20 Tahun 2008).

\subsection{SAK EMKM}

SAK EMKM merupakan standar akuntansi keuangan yang ditujukan untuk UMKM. Penerapan SAK EMKM di Indonesia berlaku efektif per Tanggal 1 Januari 2018 yang sebelumnya berupa SAK ETAP. Akan tetapi ditinjau dari penelitian sebelumnya menjelaskan bahwa hanya 36\% pemilik UMKM yang pernah mengetahui SAK ETAP (Kurniawanysah 2016). 
Standar Akuntansi di Nigeria menggunakan International Financial Reporting Standars (IFRS) untuk UKM. Meskipun IFRS untuk UKM itu mahal dan memberatkan tetapi adopsi IFRS akan meningkatkan keunggulan kompetitif, potensi pertumbuhan, keberlanjutan usaha, meningkatkan transparansi dan akuntabilitas UKM di Nigeria (Ezeagba 2017).

Penelitian di Romania menunjukkan hasil bahwa sebagian besar akuntan bersertifikat menganggap perlu adanya klasifikasi informasi dan metode akuntansi berdasarkan kategori UMKM. Karena dalam undang-undang akuntansi Romania tidak ada batasan akuntansi untuk UMKM. Akuntan bersertifikat setuju untuk menerapkan batas akuntansi lebih jauh lagi dan disesuaikan dengan kategori UMKM (Buculescu dan Stoica 2016).

\subsection{Ukuran Perusahaan, Latar Belakang Pendidikan Pemilik, dan Pemberian Informasi dan} Sosialisasi

Pelaku UMKM memiliki karakteristik yang beragam. Usaha mikro membutuhkan standar akuntansi yang lebih sederhana. Sedangkan usaha kecil dan menengah membutuhkan SAK ETAP untuk menghasilkan laporan keuangan yang berkualitas (Kurniawanysah 2016). Ukuran UKM dan jenis industri memiliki hubungan yang signifikan terhadap pelaporan keuangan UKM (Jaffar et al., 2011)

Latar belakang pendidikan pengusaha UMKM juga menjadi salah satu faktor yang mendukung implementasi SAK EMKM. Pelaku UMKM yang pernah menempuh pendidikan akuntansi mempunyai persepsi yang lebih baik terkait implementasi standar akuntansi dibandingkan dengan pengusaha yang berlatar belakang non akuntansi. Studi menunjukkan bahwa kualifikasi pedidikan pemilik UKM memiliki hubungan yang signifikan terhadap pelaporan keuangan UKM (Jaffar et al., 2011)

Salah satu faktor yang menjadi temuan peneliti sebelumnya dalam implementasi standar akuntansi ialah kurangnya informasi dan sosialisasi. Pelaku UKM di Inggris ditemukan tidak terlalu sadar financial, hanya sedikit dari mereka yang memiliki pelatihan dibidang akuntansi atau manajemen bisnis. Hal tersebut menunjukkan bahwa standar akuntansi yang dibuat untuk UKM seharusnya lebih sederhana dan mudah dimengerti (Sian dan Roberts 2009). Pelaku UMKM berpendapat bahwa masih memerlukan adanya sosialisasi standar akuntansi. Mereka berharap adanya pelatihan yang berkelanjutan dengan memberikan modul standar akuntansi untuk diimplementasikan (Kurniawanysah 2016). Pelatihan berfokus pada manajemen keuangan. Manajemen keuangan yang buruk menjadi masalah utama yang dihadapi UKM dalam mengakses pinjaman dari bank karena mereka tidak menyiapkan laporan keuangan yang baik (Kofi et al., 2014). Dari penjelasan tersebut maka hipotesis yang akan diuji dalam penelitian ini adalah, 
$\mathrm{H}_{1 \mathrm{a}}$ :Ukuran perusahaan berpengaruh signifikan terhadap implementasi SAK EMKM.

$\mathrm{H}_{1 \mathrm{~b}} \quad$ :Latar belakang pendidikan pemilik UMKM berpengaruh signifikan terhadap implementasi SAK EMKM.

$\mathrm{H}_{1 \mathrm{c}}$ :Pemberian informasi dan sosialisasi berpengaruh signifikan terhadap implementasi SAK EMKM .

$\mathrm{H}_{2} \quad$ :Impelementasi SAK EMKM berpengaruh signifikan terhadap kualitas laporan keuangan.

\subsection{Pelaporan Keuangan dan Penerimaan Kredit}

Pengambilan keputusan perusahaan memiliki potensi untuk meningkatkan kesuksesan atau justru mengarah pada kegagalan. Risiko keuangan penting untuk dievaluasi dalam pengambilan keputusan yang berkualitas. Laporan keuangan memberikan informasi penting yang harus digunakan baik oleh evaluator eksternal maupun internal (Auken 2013).

Tanpa informasi akuntansi yang berkualitas, sangat sulit bagi pengusaha untuk mengambil keputusan operasional dan strategis. Pertumbuhan dan keberlangsungan bisnis akan terhambat jika ada ketidakefisiensian operasional, pengambilan keputusan yang tidak tepat, berinvestasi dalam proyek yang salah, dll. Hal tersebut menunjukkan bahwa praktik akuntansi yang buruk menjadi ancaman bagi pertumbuhan dan keberlanjutan UKM (Chakraborty 2015).

Penyusunan laporan keuangan secara lengkap dapat meningkatkan pertumbuhan UKM. Pelaporan kinerja keuangan UKM tidak hanya terbatas pada pengguna internal tetapi juga untuk pengguna eksternal seperti pemberi pinjaman (Maseko dan Onias 2011). Kredit yang buruk untuk UKM disebabkan catatan akuntansi UKM yang tidak memadai (Kung'u 2011). Informasi dalam laporan keuangan khususnya laporan laba rugi dapat memberikan informasi kepada perbankan tentang kemampuan pengusaha UKM untuk bertahan dalam bisnis. Hal tersbut mengindikasikan bahwa UKM mampu membayar pinjaman ketika jatuh tempo (Jaffar et al., 2011)

Namun, sebagian besar UKM di Kenya mengalami kesulitan dalam mendapatkan kredit dari lembaga keuangan formal karena mereka tidak memiliki catatan keuangan yang tepat. Sebagian besar perusahaan tidak mengaudit laporan keuangan berdasarkan standar akuntansi. Pada akhirnya perusahaan-perusahaan ini mendapatkan pinjaman dengan suku bunga yang lebih tinggi karena bank menganggap mereka sebagai peminjam berisiko tinggi (Kung'u 2011). Penelitian di Nigeria menunjukkan bahwa pencatatan keuangan, pembukuan yang baik, sumberdaya yang berkualitas, penggunaan sistem informasi akuntansi, dan keterlibatan bank dalam transaksi dapat meningkatkan fasilitas kredit yang diberikan oleh bank kepada UKM (Ezeagba 2017). Oleh karena itu, UKM harus lebih proaktif untuk memenuhi kebutuhan 
pengguna laporan keuangan jika mereka ingin bertahan dan tumbuh dalam perekonomian (Jaffa et al., 2011). Dari penjelasan tersebut maka hipotesis yang akan diuji dalam penelitian ini adalah:

$\mathrm{H}_{3}$ : Kualitas laporan keuangan UMKM berpengaruh signifikan terhadap penerimaan kredit UMKM

Penelitian ini dilakukan mengingat pentingnya penyusunan laporan keuangan bagi UMKM untuk akses pendanaan. Sehingga UMKM di Indonesia diharapkan dapat terus berkembang dan sustainable. Perbedaan penelitian ini dengan penelitian sebelumnya yaitu penelitian ini menguji faktor yang mempengaruhi implementasi SAK EMKM. SAK EMKM merupakan standar akuntansi keuangan terbaru yang disusun oleh DSAK yang ditujukan untuk UMKM. Sedangkan penelitian terdahulu menguji standar akuntansi keuangan sebelumnya yaitu SAK ETAP. Selain standar akuntansi yang berbeda, lokasi penelitian ini juga berbeda dengan penelitian sebelumnya. Penelitian terdahulu diuraikan dalam tabel berikut,

Tabel 2.1.Penelitian Terdahulu

\begin{tabular}{|c|c|c|c|c|}
\hline No. & Nama Peneliti & Judul & Metode Penelitian & Kesimpulan \\
\hline 1 & $\begin{array}{l}\text { Rudiantoro \& } \\
\text { Siregar (2012) }\end{array}$ & $\begin{array}{l}\text { Kualitas Laporan } \\
\text { Keuangan UMKM } \\
\text { Serta Prospek } \\
\text { Implementasi SAK } \\
\text { ETAP }\end{array}$ & $\begin{array}{l}\text { Penelitian ini } \\
\text { menggunakan pendekatan } \\
\text { kuantitatif dengan variabel } \\
\text { dependen: persepsi } \\
\text { UMKM, penerimaan kredit, } \\
\text { pemahaman UMKM. } \\
\text { Variabel independen: } \\
\text { pendidikan terakhir, latar } \\
\text { belakang pendidikan } \\
\text { responden, ukuran usaha, } \\
\text { lama usaha, besarnya } \\
\text { jaminan kredit, termin } \\
\text { kredit, pemberian } \\
\text { informasi dan sosialisasi }\end{array}$ & $\begin{array}{l}\text { Kualitas laporan } \\
\text { keuangan UMKM tidak } \\
\text { berpengaruh terhadap } \\
\text { jumlah kredit yang } \\
\text { diterima UMKM. Hal ini } \\
\text { dikarenakan masih } \\
\text { redahnya kualitas laporan } \\
\text { keuangan UMKM } \\
\text { sehingga perbankan } \\
\text { masih meragukan } \\
\text { relevansi dan keandalan } \\
\text { kualitas laporan } \\
\text { keuangannya. Prospek } \\
\text { impelemntasi SAK ETAP } \\
\text { terhadap peningkatan } \\
\text { kualitas laporan } \\
\text { keuangan masih } \\
\text { menghadapi kendala } \\
\text { akibat masih rendahnya } \\
\text { pemahaman para } \\
\text { pengusaha UMKM atas } \\
\text { SAK ETAP. }\end{array}$ \\
\hline 2 & $\begin{array}{l}\text { Rahmawati \& } \\
\text { Puspasari ( 2017) }\end{array}$ & $\begin{array}{l}\text { Implementasi SAK } \\
\text { ETAP Dan Kualitas } \\
\text { Laporan Keuangan } \\
\text { UMKM Terhadap } \\
\text { Akses Modal } \\
\text { Perbanan }\end{array}$ & $\begin{array}{l}\text { Metode penelitian ini } \\
\text { menggunakan pendekatan } \\
\text { kuantitatif. Variable yang } \\
\text { digunakan meliputi } \\
\text { kemudahan akses } \\
\text { permodalan sebagai } \\
\text { variable dependen. } \\
\text { Kualiats laporan keuangan } \\
\text { dan prospek } \\
\text { impelementasi SAK ETAP }\end{array}$ & $\begin{array}{l}\text { Ukuran usaha, lama } \\
\text { usaha berdiri, pemberian } \\
\text { informasi dan sosialisasi } \\
\text { SAK ETAP, latar } \\
\text { belakang dan jenjang } \\
\text { pendidikan terkahir } \\
\text { pelaku usaha, serta } \\
\text { profesionalisme } \\
\text { manajemen berpengaruh } \\
\text { terhadap pemahaman }\end{array}$ \\
\hline
\end{tabular}




\begin{tabular}{|c|c|c|c|c|}
\hline & & & $\begin{array}{l}\text { sebagai variable } \\
\text { independen }\end{array}$ & $\begin{array}{l}\text { pelaku UMKM terkait } \\
\text { implementasi SAK ETAP } \\
\text { Dampak dari } \\
\text { implementasi SAK ETAP } \\
\text { memberikan indikasi kuat } \\
\text { bahwa kualitas laporan } \\
\text { keuangan berpengaruh } \\
\text { terhadap besarnya } \\
\text { kemudahan akses modal } \\
\text { perbankan. }\end{array}$ \\
\hline 3 & $\begin{array}{l}\text { Prajanto \& } \\
\text { Septriana (2018) }\end{array}$ & $\begin{array}{l}\text { Implementasi } \\
\text { Penerapan SAK } \\
\text { EMKM serta } \\
\text { Dampaknya pada } \\
\text { Kualitas Pelaporan } \\
\text { Keuangan UMKM } \\
\text { (Studi Kasus Pada } \\
\text { UMKM Se Kota } \\
\text { Semarang }\end{array}$ & $\begin{array}{l}\text { Metode penelitian ini } \\
\text { menggunakan pendekatan } \\
\text { kuantitatif. Variabel yang } \\
\text { diguanakan meliputi } \\
\text { variabel independen: } \\
\text { jenjang pendidikan dan } \\
\text { latar belakang pendidikan } \\
\text { responden, Skala Usaha, } \\
\text { Usia perusahaan, kualitas } \\
\text { laporan keuangan, } \\
\text { Jaminan, termin kredit, } \\
\text { dan pemberian informasi } \\
\text { dan sosialisasi. Variabel } \\
\text { dependen meliputi: } \\
\text { Persepsi Pengusaha, } \\
\text { Penerimaan Kredit, dan } \\
\text { pemahaman pelaku atas } \\
\text { SAK EMKM. }\end{array}$ & $\begin{array}{l}\text { Hasil penelitian ini } \\
\text { menunjukkan bahwa } \\
\text { persepsi pengusaha atas } \\
\text { laporan keuangan masih } \\
\text { sangat rendah sehingga } \\
\text { mengakibatkan kualitas } \\
\text { laporan keuangan yang } \\
\text { dibuat pengusaha UMKM } \\
\text { tidak berpengaruh pada } \\
\text { besaran kredit yang } \\
\text { diperoleh UMKM. } \\
\text { Prospek implementasi } \\
\text { SAK EMKM terhadap } \\
\text { kualitas laporan } \\
\text { keuangan saat ini masih } \\
\text { sangat minim karena } \\
\text { pengusaha masih rendah } \\
\text { dalam memahami } \\
\text { pembukuan sesuai } \\
\text { dengan SAK EMKM. }\end{array}$ \\
\hline
\end{tabular}

\section{Metodologi Penelitian}

Penelitian ini menggunakan pendekatan kuantitatif dengan metoda survei yaitu mendistribusikan kuesioner kepada UMKM yang ada di Daerah Istimewa Yogyakarta (DIY). Teknik pengambilan sampel dalam penelitian ini adalah random sampling. Data yang sudah terkumpul diolah menggunakan SPSS dan alat uji hipotesis menggunakan regresi berganda dengan nilai signifikansi 0.05 . Berikut model penelitian yang digunakan dalam penelitian ini, Model 1 IMP_SAK $=\alpha+\beta_{1} S I Z E+\beta_{2} E D \_B A C K G+\beta_{3} I N F \_S O S+e$

Model 2 QUAL_FP $=a+\beta$ IMP_SAK $+e$

Model 3 KRD_REC $=\alpha+\beta$ QUAL_FR $+e$

Keterangan:

IMP_SAK = Implementasi SAK EMKM

SIZE $\quad=$ Ukuran Perusahaan

ED_BACKG = Latar Belakang Pendidikan Responden

INF_SOS = Pemberian Informasi dan Sosialisasi SAK EMKM

QUAL_FR = Kualitas Laporan Keuangan 


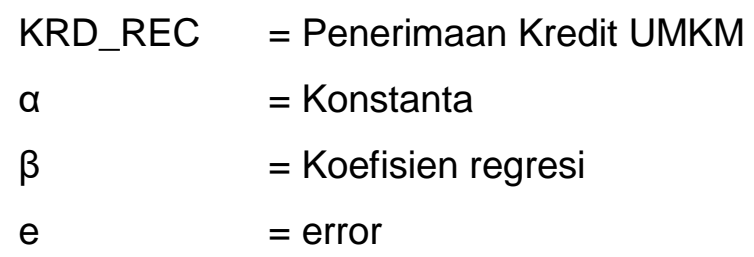

Pengukuran variabel penelitian merupakan pengembangan dari penelitian Rudiantoro \& Siregar (2012). Pengukuran variabel dalam penelitian ini adalah:

\subsection{Ukuran Perusahaan}

1. Aset Bersih Perusahaan: a. < dari Rp 100 juta, b. Rp. 100 juta-Rp.499 juta, c. Rp. 500 jutaRp. 2.5 miliar, dan d. > dari Rp 2.5 miliar.

2. Omset perusahaan pertahun:a. < dari Rp 100 juta, b. Rp. 100 juta-Rp.499 juta, c. Rp. 500 juta- Rp. 2.5 miliar, dan d. > dari Rp 2.5 miliar.

Masing-masing pilihan akan diberi nilai 1 untuk jawaban "a", 2 untuk jawaban "b", 3 untuk "c", dan "4" untuk "d". Nilai dari kedua pertanyaan dijumlahkan dan berdasarkan hasil penjumlahan tersebut ukuran usaha dikelompokkan menjadi kelompok usaha mikro untuk nilai antara $1-4$, usaha kecil antara $5-6$, dan untuk nilai $>6$ tergolong usaha menengah.

\subsection{Latar Belakang Pendidikan Pemilik}

Latar belakang pendidikan responden terdiri atas: a. Akuntansi, b. Manajemen/ekonomi, dan c. Lainnya. Jika mempunyai latar belakang pendidikan Akuntansi diberi nilai 3, sedangkan jika berlatar belakang pendidikan Manajemen dan Ekonomi diberi nilai 2, serta untuk latar belakang pendidikan lainnya mendapat nilai 1 .

\subsection{Pemberian Informasi dan Sosialisasi}

Variabel ini diukur dengan menjumlahkan nilai dari jawaban yang diberikan atas pertanyaan berikut:

1. Apakah responden sudah mengetahui sebelumnya tentang SAK EMKM , jika menjawab "Ya" mendapat nilai 1, dan jika "Tidak" mendapat nilai 0 .

2. Responden mengetahui SAK EMKM dari:a. Seminar, b. Pelatihan, c.Internet, d.Buletin/ Majalah, dan e. Lainnya (sebutkan). Setiap pilihan jawaban atas pertanyaan ini mendapat poin 1. 
3. Apakah responden pernah mengikuti sosialisasi atau pelatihan tentang SAK EMKM? Jika menjawab "Ya" maka mendapat nilai1 dan jika "Tidak" akan mendapat nilai 0.

\subsection{Kualitas Laporan Keuangan}

Dalam penelitian ini kualitas laporan keuangan dinilai berdasarkan:

1. Apakah responden melakukan pembukuan akuntansi atau tidak, jika menjawab "Ya" maka mendapat nilai 1, dan jika "tidak" mendapat nilai 0.

2. Apakah responden menggunakan aplikasi akuntansi yang mendukung pembukuan atau tidak, jika menjawab "Ya" maka mendapat nilai 1, dan jika "tidak" mendapat nilai 0.

3. Standar akuntansi apa yang digunakan oleh responden: a. SAK EMKM, aturan perpajakan, lainnya (sebutkan), dan b. Tidak menggunakan aturan apapun. Jika menjawab a diberi nilai 1 , dan jika menjawab b diberi nilai 0 ".

\subsection{Penerimaan Kredit.}

Besaran kredit yang diterima oleh responden dari perbankan atau lembaga keuangan lainnya: a. < dari Rp10.000.000, b. Rp 10.000.001 - Rp 25.000.000, c.Rp 25.000.001 - Rp 50.000.000, d. Rp50.000.001 - Rp 100.000.000, dan e. > Rp100.000.000. Masing-masing pilihan mendapatkan nilai 1 untuk pilihan a, 2 untuk pilihan b, 3 untuk pilihan c, 4 untuk pilihan d, dan 5 untuk pilihan e.

\section{Analisis dan Pembahasan}

Responden dari penelitian ini sejumlah 113 dari 115 kuesioner yang disebar di wilayah Yogyakarta. 2 kuesioner tidak terjawab sesuai dengan yang dibutuhkan dalam penelitian ini. Dari data yang telah dikumpulkan, informasi responden dapat diketahui bahwa responden pada penelitian ini sebagian besar adalah pemilik UMKM dengan jenis usaha mayoritas manufaktur ( produksi barang). Jenjang pendidikan pelaku UMKM didominasi oleh lulusan SMA/SMK dengan jurusan bukan akuntansi maupun ekonomi (Manajemen dan ilmu ekonomi). Skala usaha responden sebagian besar adalah skala mikro dengan 12 responden yang mengimplementasikan SAK EMKM, 60 responden yang melakukan pembukuan keuangan dan 18 responden yang menerima kredit. 
Tabel 4.1 Hasil Regresi Model 1

\begin{tabular}{|c|c|c|c|c|c|c|}
\hline \multirow{2}{*}{\multicolumn{2}{|c|}{ Model }} & \multicolumn{2}{|c|}{$\begin{array}{c}\text { Unstandardized } \\
\text { Coefficients }\end{array}$} & \multirow{2}{*}{$\begin{array}{c}\text { Standardized } \\
\text { Coefficients } \\
\text { Beta }\end{array}$} & \multirow[t]{2}{*}{$t$} & \multirow[t]{2}{*}{ Sig. * } \\
\hline & & B & Std. Error & & & \\
\hline \multirow{4}{*}{1} & (Constant) & -.058 & .082 & & -.712 & .478 \\
\hline & SIZE & .002 & .016 & .007 & .148 & .882 \\
\hline & ED-BACKG & .014 & .022 & .028 & .641 & .523 \\
\hline & INF_SOS & .483 & .024 & .887 & 20.188 & .000 \\
\hline
\end{tabular}

Hasil pengujian regresi model 1, IMP_SAK $=\alpha+\beta_{1} S I Z E+\beta_{2} E D \_B A C K G+\beta_{3} I N F \_S O S+e$. Variabel ukuran perusahaan (SIZE) menunjukkan nilai sig. 0.88. Nilai signifikansi tersebut lebih besar 0.05 yang artinya ukuran perusahaan (SIZE) tidak berpengaruh signifikan terhadap implementasi SAK EMKM ( $\mathrm{H}_{1 \mathrm{a}}$ ditolak). Ukuran perusahaan responden dalam penelitian ini sebagian besar berskala mikro. Omset dan aset perusahaan masih terbilang kecil serta pembukuan yang disusun oleh pelaku UMKM masih tergolong sederhana. Sehingga, mereka tidak membutuhkan pembukuan yang rumit dan bahkan sebagian dari pelaku UMKM tidak melakukan pembukuan sama sekali.

Pembukuan secara akuntansi penting bagi UMKM. Seiring bertumbuhnya skala perusahaan, pembukuan secara akuntansi semakin dibutuhkan. Tidak hanya untuk mendapatkan kredit dari pemberi pinjaman, akan tetapi untuk mengetahui sehat atau tidaknya keuangan perusahaan. Pelaku UMKM tidak hanya mebutuhkan informasi keuntungan dan kerugiannya saja, akan tetapi mereka harus mengetahui besarnya piutang perusahaan, nilai persediaan, nilai aset, hutang dan modal perusahaan sebagai dasar evaluasi kinerja perusahaan. Oleh karena itu penting bagi UMKM untuk memulai menyusun pembukuan secara akuntansi meski skala usaha masih tergolong mikro.

Hasil penelitian ini konsisten dengan Prajonto dan Septriana (2018) yang menunjukkan hasil bahwa skala usaha UMKM tidak berpengaruh signifikan terhadap pemahaman pelaku UMKM atas SAK EMKM. Hal tersebut disebabkan oleh pelaku usaha mikro lebih fokus pada upaya menaikkan omset dan usaha yang berkelanjutan dari pada memahami SAK EMKM.

Variabel latar belakang pendidikan responden (ED_BACKG) menunjukkan nilai sig. 0.52. Nilai signifikansi tersebut lebih besar dari 0.05 yang artinya variabel latar belakang pendidikan responden (ED_BACKG) tidak berpengaruh signifikan terhadap implementasi SAK 
EMKM ( $\mathrm{H}_{1 \mathrm{~b}}$ ditolak). Responden penelitian ini mempunyai latar belakang pendidikan yang variatif. Latar belakang pendidikan responden yang kurang dari SMA/ SMK sebesar 26\%, SMA/ SMK sebesar $46 \%$, Jenjang S1 sebesar $24 \%$, dan jenjang S2 sebesar $4 \%$ Dengan jurusan bukan akuntansi maupun ekonomi sebesar 85\%. Dari data tersebut dapat diketahui bahwa sebagian besar responden dalam penelitian ini adalah lulusan SMA/SMK dengan jurusan bukan akuntansi maupun ekonomi.

Responden yang mengimplemntasikan SAK EMKM sejumlah 12 responden. Hal tersebut disebabkan oleh latarbelakang pendidikan responden yang bukan dari akuntansi dan tidak memiliki pemahaman tentang akuntansi. Jika pelaku UMKM mempekerjakan tenaga ahli akuntansi tentunya akan menambah pengeluaran mereka. Sehingga pelaku UMKM membiarkan transaksi mereka tanpa tercatat. Dalam hal ini peran teknologi sangat penting untuk memudahkan pelaku UMKM dalam menyusun pembukuan secara akuntansi. Pelaku UMKM dapat mengunduh aplikasi akuntansi secara gratis yang banyak tersedia di internet. Pelaku UMKM juga dapat berlangganan aplikasi akuntansi berbayar, hal tersebut lebih efisien dibandingkan dengan mengeluarkan biaya untuk membayar tenaga ahli akuntansi. Tentu saja hal ini memerlukan penguasaan teknologi yang baik dari pelaku UMKM.

Variabel informasi dan sosialisasi (INF_SOS) menunjukkan nilai sig. 0.00. Nilai signifikansi tersebut lebih kecil dari 0.05 yang artinya variabel pemberian informasi dan sosialisasi (INF_SOS) berpengaruh signifikan terhadap implementasi SAK EMKM $\left(\mathrm{H}_{1 \mathrm{c}}\right.$ diterima). Responden yang menjawab telah mengimplementasikan SAK EMKM sebelumnya mendapatkan sosialiasi terkait pentingnya pembukuan secara akuntansi. Pelaku UMKM mendapatkan informasi dan sosialisasi mengenai SAK EMKM melalui seminar/pelatihan. Akan tetapi, jika dilihat dari laporan keuangan yang telah mereka susun hanya terdiri atas laporan arus kas dan laporan laba rugi. Sehingga, pemberian informasi dan sosialisi yang dimaksud adalah masih sebatas cara pembukuan dasar seperti catatan banyaknya uang yang masuk dan keluar serta saldo yeng tersisa.

Hasil penelitian ini konsisten dengan penelitian Rudiantoro dan Siregar (2012) yang menunjukkan hasil bahwa variabel informasi dan sosialisasi berpengaruh positif signifikan terhadap pemahaman pengusaha UMKM atas SAK ETAP. Dari responden yang mengetahui SAK ETAP, sebelumnya telah mendapatkan informasi dan sosialisasi terkait SAK ETAP dari bank pemberi pinjaman dan UKM Centre. Sehingga pemberian informasi dan sosialisasi berpengaruh terhadap pemahaman pelaku UMKM terkait SAK ETAP. 
Tabel 4.2 Hasil Regresi Model 2

\begin{tabular}{|c|c|c|c|c|c|}
\hline \multirow[t]{2}{*}{ Model } & \multicolumn{2}{|c|}{$\begin{array}{l}\text { Unstandardized } \\
\text { Coefficients }\end{array}$} & \multirow{2}{*}{$\begin{array}{c}\text { Standardized } \\
\text { Coefficients } \\
\text { Beta }\end{array}$} & \multirow[t]{2}{*}{$t$} & \multirow[t]{2}{*}{ Sig.* } \\
\hline & B & Std. Error & & & \\
\hline (Constant) & 6.992 & .413 & & 16.934 & .000 \\
\hline IMP_SAK & 1.455 & .694 & .195 & 2.096 & .038 \\
\hline
\end{tabular}

Dependent Variable: QUAL_F=kualitaslaporankeuangan=, IMP_SAK= Implementasi SAK EMKM,

*Signifikansi=0.05

Hasil regresi model 2, QUAL_FP $=a+\beta I M P \_S A K+e$, menunjukkan hasil signifikansi dari variabel implementasi SAK EMKM (IMP_SAK) sebesar 0.038. Nilai tersebut lebih kecil dari nilai signifikansi 0.05 yang artinya variabel implementasi SAK EMKM (IMP_SAK) berpengaruh signifikan terhadap kualitas laporan keuangan $\left(\mathrm{H}_{2}\right.$ diterima). Responden dalam penelitian ini sebagian besar tidak mengimplemntasikan SAK EMKM. Jika responden memahami dan mengimplementasikan SAK EMKM dengan baik, tentunya laporan keuangan mereka lebih berkualitas. Hal ini dibutuhkan pelatihan yang berkelanjutan dan komprehensif dari Pembina UMKM atau Lembaga yang menaungi UMKM.

Tabel 4.3 Hasil Regresi Model 3

\begin{tabular}{|c|c|c|c|c|c|}
\hline \multirow[t]{2}{*}{ Model } & \multicolumn{2}{|c|}{$\begin{array}{l}\text { Unstandardized } \\
\text { Coefficients }\end{array}$} & $\begin{array}{l}\text { Standardized } \\
\text { Coefficients }\end{array}$ & $\mathrm{t}$ & Sig. ${ }^{*}$ \\
\hline & B & Std. Error & Beta & & \\
\hline (Constant) & 3.641 & .734 & & 4.961 & .000 \\
\hline QUAL-FR & -.022 & .087 & -.024 & -.255 & .799 \\
\hline
\end{tabular}

Dependent Variable: KRD_REC= penerimaan kredit UMKM, QUAL_FR=Kualitas laporan keuangan. ${ }^{*}$ Signifikansi $=0.05$

Hasil pengujian regresi model 3, Model $3 \mathrm{KRD}$ REC $=\alpha+\beta \mathrm{QUAL} F \mathrm{FR}+\mathrm{e}$, menunjukkan hasil bahwa variabel kualitas laporan keuangan (QUAL_FR) menunjukkan nilai sig. 0.79. Nilai signifikansi tersebut lebih besar 0.05 yang artinya variabel kualitas laporan keuangan tidak berpengaruh signifikan terhadap penerimaan kredit UMKM $\left(\mathrm{H}_{3}\right.$ ditolak). Mayoritas responden dalam penelitian ini adalah pemilik usaha dengan skala mikro yang melakukan pembukuan secara sederhana dan bahkan ada yang tidak melakukan pembukuan sama sekali. Meskipun kualitas laporan keuangan responden rendah, pelaku UMKM tetap bisa menerima pinjaman dari bank dengan menggunakan jaminan yaitu berupa aset tetap yang dimiliki oleh pelaku 
UMKM. Responden merasa tidak ada kesulitan dalam memperoleh kredit dari bank maupun lembaga keuangan lainnya. Hal tersebut dikarenakan bank dan lembaga keuangan lain terus berinovasi dalam meningkatkan layanan. Sehingga pemberian kredit kepada pelaku UMKM dimudahkan untuk menarik nasabah agar terus menggunakan jasa mereka.

Hasil penelitian ini sependapat dengan Prajanto dan Septriana (2018) yang menyatakan bahwa kualitas laporan keuangan tidak berpengaruh terhadap jumlah kredit yang diterima UMKM. Hal tersebut disebabkan oleh perbankan tidak menjadikan kualitas laporan keuangan sebagai alat untuk memberikan kredit kepada UMKM. Perbankan cenderung melihat omset yang dihasilkan oleh UMKM. Rudiantoro dan Siregar (2012) mengungkapkan hasil penelitian bahwa kualitas laporan keuangan UMKM tidak dijadikan acuan pemberian kredit karena laporan keuangan UMKM belum menjadi sumber informasi yang andal dan relevan bagi perbankan dalam arti masih sangat sederhana.

\section{Kesimpulan, Keterbatasan, dan Saran}

\subsection{Kesimpulan}

Variabel Ukuran perusahaan (SIZE) dan Latar belakang pendidikan responden (ED_BACKG) tidak berpengaruh signifikan terhadap implementasi SAK EMKM $\left(\mathrm{H}_{1 \mathrm{a}}\right.$ dan $\mathrm{H}_{1 \mathrm{~b}}$ ditolak). Ukuran perusahaan responden dalam penelitian ini mayoritas berskala mikro. Pelaku UMKM lebih berupaya untuk meningkatkan omset dan fokus dalam mengembangkan usaha dibandingkan dengan membuat laporan keuangan yang sesuai dengan standar akuntansi. Disamping itu, Latar belakang pendidikan responden didominasi oleh lulusan SMA/SMK dengan jurusan bukan akuntansi sehingga mereka sama sekali tidak memiliki pemahaman atas SAK EMKM. Oleh sebab itu, pemberian informasi dan sosialisasi perlu dilakukan agar pelaku UMKM lebih memahami dan mampu menyusun laporan keuangan secara akuntansi. Jika responden memahami dan mengimplementasikan SAK EMKM dengan baik, tentunya laporan keuangan mereka lebih berkualitas $\left(\mathrm{H}_{2}\right.$ diterima). Hal ini dibutuhkan pelatihan yang berkelanjutan dan komprehensif dari Pembina UMKM atau Lembaga yang menaungi UMKM.

Variabel kualitas laporan keuangan (QUAL_FR) tidak berpengaruh signifikan terhadap penerimaan kredit UMKM $\left(\mathrm{H}_{3}\right.$ ditolak). Kualitas laporan keuangan yang masih rendah tidak menghalangi pelaku UMKM dalam memperoleh kredit dari perbankan maupun lembaga keuangannya lainnya. Pelaku UMKM tetap bisa menerima pinjaman dengan memberikan jaminan yaitu berupa aset tetap yang dimiliki oleh pelaku UMKM. 


\subsection{Keterbatasan dan Saran}

Keterbatasan penelitian ini adalah variabel-variabel yang diuji dalam penelitian ini merupakan pengembangan dari penelitian sebelumnya. Sehingga saran untuk penelitian selanjutnya, peneliti dapat menambahkan variabel baru seperti variabel kesadaran dan kemauan pelaku UMKM untuk menyusun laporan keuangan berdasarkan SAK EMKM. Hasil penelitian menunjukkan bahwa bukan skala usaha maupun latar belakang pendidikan yang mempengaruhi pelaku UMKM dalam mengimplementasikan SAK EMKM, akan tetapi pemberian informasi dan sosialisasi serta kemauan pelaku UMKM untuk mengimplementasikan SAK EMKM tersebut.

\section{Daftar Pustaka}

Auken, Howard V. 2013. Influences on Frequency of Preparation of Financial Statements Among SMEs. Journal of Innovation Management. Vol. 1, No. 1, pp. 143-157.

Buculescu, M. M. And Stoica, A. 2016. A Survey of Certified Accountants Opinion on SMEs Financial Reporting: Evidence from Romania. Journal of Economics, Business and Management.Vol. 4, No. 1, pp.7-14

Chakraborty, Ashok. 2015. Impact of Poor Accounting Practices on the Growth and Sustainability of SMEs. The International Journal Of Business \& Management. Vol 3, Issue 5, pp. 227-231.

Clementina, K.., Egwu, ON and Isu, G. 2014. Small and Medium Enterprises in Nigeria and Adoption of International Financial Reporting Standards.An Evaluation. IOSR Journal of Economics and Finance.Volume 4, Issue 2. PP 27-32.

Departemen Koperasi. 2013. depkop.go.id/berita-informasi/data-informasi/data-umkm/. Diakses pada Tanggal 10 Agustus 2018 Pukul 10.00

DSAK. 2016. Exposure Draft Standar Akuntansi Keuangan Entitas Mikro Kecil dan Menengah.

Ezeagba, Charles Emenike. 2017. Financial Reporting in Small and Medium Enterprises (SMEs) in Nigeria. Challenges and Options.International Journal of Academic Research in Accounting, Finance and Management Sciences. Vol. 7, No.1, pp. 1-10

Jaffar, N.,Selamat, Z.,Ismail, N and Hamzah, H. 2011. Small Medium Enterprises' Financial Reporting In Malaysia.Corporate Ownership \& Control. Vol.8, Issue 3, pp. 366-375.

Kofi,M.E.,Adjei, H.,Collins,M.,and Christian, A.O.A. (2014). Assessing Financial Reporting Practices Among Small Scale Enterprises in kumasi Metropoliton Assembly. European Journal of Business and Social Sciences. Vol. 2, No.10, pp.81-96 
Kung'u, Gabriel Kamau. 2011. Factors Influencing Small and Medium Enterprises' Access to Funding in Kenya: A Case Study of Westlands Division. Munich Personal RePEc Archive. MPRA Paper No. 66633, pp1-27

Kurniawanysah, D. 2016. Penerapan Pencatatan Akuntansi Dan Penyusunan Laporan Keuangan Bberdasarkan SAK ETAP Pada UMKM Desa Gembonghsari Kecamatan Kalipuro Kabupaten Banyuwangi. Prosiding Seminar Nasional, Dinamika Global : Rebranding Keunggulan Kompetitif Berbasis Kearifan Lokal.Gedung Pascasarjana UNEJ.

Maseko, N and Onias. M. 2011. Accounting practices of SMEs in Zimbabwe: An investigative study of record keeping for performance measurement (A case study of Bindura). Journal of Accounting and Taxation. Vol. 3, No. 8 , pp. 171-181

Narsa, Niluh Putu Dian Rosalina Handayani, dan Isnalita Isnalita. 2017. SAK ETAP SEBAGAI SOLUSI OVERLOAD STANDAR AKUNTANSI BAGI UMKM. EKUITAS (Jurnal Ekonomi dan Keuangan) 1 (1) (2017): 44-65.

Prajanto \& Septriana. 2018. Implementasi Penerapan SAK EMKM serta Dampaknya pada Kualitas Pelaporan Keuangan UMKM (Studi Kasus Pada UMKM Se Kota Semarang).Jurnal Aset. Vol. 20, No.2, pp. 79-89

Rahmawat, T \& Puspasari, O. R. 2017. Implementasi SAK ETAP Dan Kualitas Laporan Keuangan UMKM Terkait Akses Modal Perbankan. Jurnal Kajian Akuntansi. Vol.1, No. 1, hal. 45-58

Republik Indonesia. 2008. Undang-undang Republik Indonesia No. 20 Tentang Usaha Mikro, Kecil, dan Menengah.

Rudiantoro, R \& Siregar, S. V. 2012. Kualitas Laporan Keuangan UMKM Serta Prospek Implementasi SAK ETAP. Jurnal Akuntansi dan Keuangan Indonesia.Vol. 9, No. 1, hal. $1-21$

Siagian, R. P. \& Pangemanan, S. S. 2016. Analisis Penyajian Laporan Keuangan Berdasarkan SAK-ETAP Pada Koperasi Karyawan Bank Sulut Go. Jurnal EMBA. Vol.4 No.1, Hal. $1450-1460$

Sian, S. And C. Roberts. 2009. UK small owner-managed businesses: accounting and financial reporting needs. Journal of Small Business and Enterprise Development.Vol. 16 No. 2, pp. 289-305. 
